\title{
Réunion, a sentinel territory for influenza surveillance in Europe
}

\author{
L Filleul (Laurent.Filleul@ars.sante.fr) ${ }^{1}$, E Brottet ${ }^{1}$, B A Gauzere ${ }^{2}$, A Winer ${ }^{3}$, D Vandroux ${ }^{2}$, A Michault ${ }^{4}$, M C Jaffar-Bandjee \\ S Larrieu ${ }^{1}$ \\ 1. Cire océan Indien (Cire OI), Institut de Veille Sanitaire (InVS), Saint Denis, Réunion, France \\ 2. Intensive Care Unit, Regional Hospital Centre of Saint-Denis, Réunion, France \\ 3. Intensive Care Unit, Regional Hospital Centre of Saint-Pierre, Réunion, France \\ 4. Laboratory of Biology-Parasitology-Virology-Hygiene, Regional Hospital Centre of Saint-Pierre, Réunion, France \\ 5. Laboratory for Microbiology, Regional Hospital Centre of Saint-Denis, Réunion, France
}

Citation style for this article:

Filleul L, Brottet E, Gauzere BA, Winer A, Vandroux D, Michault A, Jaffar-Bandjee MC, Larrieu S. Réunion, a sentinel territory for influenza surveillance in Europe. Euro Surveill. 2012;17(27):pii=20212. Available online: http://www.eurosurveillance.org/ViewArticle.aspx?Articleld=20212

Article submitted on 3 February 2012 / published on 5 July 2012

In Réunion, a French overseas territory located in the southern hemisphere, increase in influenza activity is generally observed several months earlier than in Europe. Influenza activity is monitored in Réunion through a multi-source surveillance system including sentinel practitioners network, hospital emergency department, laboratory and mortality. Since 2009, three successive influenza epidemics occurred on the island. The largest was observed in 2009 while epidemics in 2010 and 2011 were much weaker. In terms of circulating strains, B viruses were predominant at the beginning of the 2009 epidemic but they were completely evicted once $\mathrm{A}\left(\mathrm{H}_{1} \mathrm{~N}_{1}\right)$ pdmog circulation started. In 2010, $\mathrm{A}\left(\mathrm{H}_{1} \mathrm{~N}_{1}\right)$ pdmog virus was predominant again, but a constant co-circulation of $B$ viruses was observed. In 2011, $\mathrm{A}\left(\mathrm{H}_{3} \mathrm{~N}_{2}\right)$ virus circulated. The same viruses were identified a few months later in mainland France in the respective seasons. Since 2009, virus circulation, epidemiological trends and health impact of influenza have been similar to those observed in Europe. Influenza surveillance in Réunion may therefore give reliable early information which should be considered apart from the surveillance in mainland France. Then, it might be even a more suitable predictor for Europe than other temperate southern hemisphere countries.

\begin{abstract}
Introduction
Réunion, a French overseas territory with 840,000 inhabitants (2011 estimate [1]), is located in the southern hemisphere in the south-western Indian Ocean. It is $700 \mathrm{~km}$ east of Madagascar and $200 \mathrm{~km}$ south-west of Mauritius, above the Tropic of Capricorn. The island benefits from a healthcare system similar to mainland France and epidemiological surveillance has been developed by the regional office of the French Institute for Public Health Surveillance (Cire OI) based on the surveillance system of mainland France [2]. Despite the distance of $9,300 \mathrm{~km}$ between Réunion and France, the island is directly connected to Europe with four daily flights to France.
\end{abstract}

The interest of monitoring influenza in temperate southern hemisphere countries has been recently underlined because it may give an indication of what will happen in Europe during the following winter [3]. Because of its location and a surveillance system similar to the one in France, Réunion can also provide suitable information in terms of prevision. Indeed, as seasons are inverted compared with those in the northern hemisphere, increase in influenza activity is observed on the island during the 'austral' winter (June-July), i.e. several months before Europe. Information collected

TABLE 1

Indicators collected continuously through influenza surveillance system, Réunion, France

\begin{tabular}{|c|c|c|c|}
\hline Source & Indicators & Frequency & Starting year \\
\hline Mortality records & $\begin{array}{l}\text { - Total number of deaths } \\
\text { - Number of death certificates with mention of influenza } \\
\text { - Death in intensive care units and detection of influenza virus (PCR for influenza) }\end{array}$ & Daily & $\begin{array}{l}2006 \\
2008 \\
2009\end{array}$ \\
\hline $\begin{array}{l}\text { Emergency } \\
\text { departments and } \\
\text { hospital wards }\end{array}$ & $\begin{array}{l}\text { - Total number of emergency room visits } \\
\text { - Emergency room visits for acute respiratory infections (number and percentage) } \\
\text { - Severe cases of influenza (number, severity and outcome) }\end{array}$ & Daily & 2009 \\
\hline $\begin{array}{l}\text { Reference hospital } \\
\text { laboratory }\end{array}$ & $\begin{array}{l}\text { - Total number of samples for influenza analysis } \\
\text { - Number of positive tests for influenza virus (PCR for influenza virus) } \\
\text { - Type of influenza virus (PCR for influenza virus) }\end{array}$ & Weekly & 1998 \\
\hline
\end{tabular}


Weekly consultations for acute respiratory infections and number of samples positive for influenza viruses, Réunion, France, 2009-2011

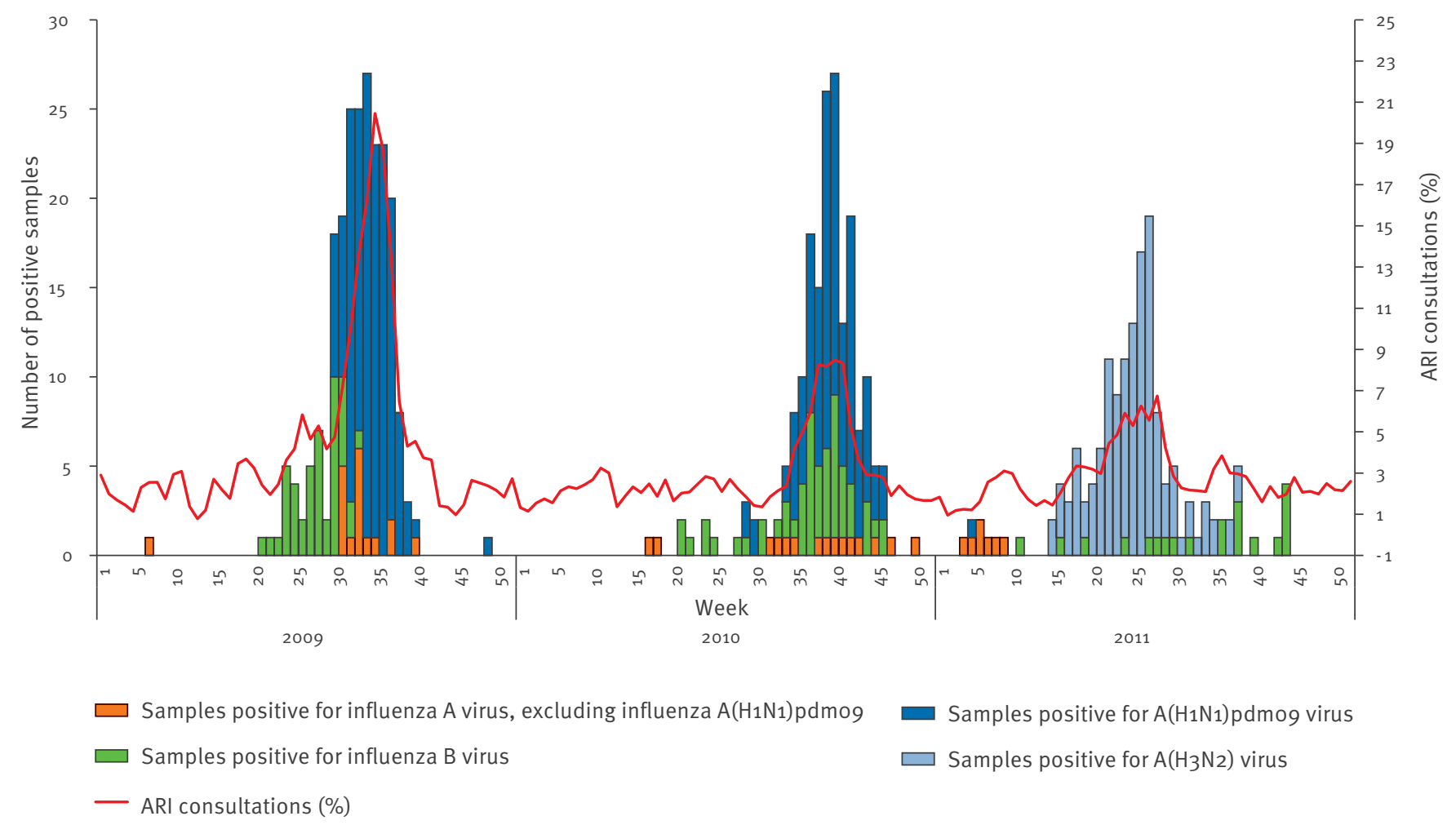

ARI: acute respiratory infection.

Source: sentinel practitioner network.

can thus be the same as that observed in Europe a few months later.

The aim of this paper is to present the main results from the surveillance system for influenza in Réunion from 2009 to 2011 in order to assess whether this territory should be considered as an interesting sentinel for influenza surveillance.

\section{Methods}

In Réunion, influenza activity has been monitored since 1996 through a sentinel practitioner network [4]. During the influenza $A\left(\mathrm{H}_{1} \mathrm{~N}_{1}\right)$ pdmog pandemic, a multisource surveillance system has been developed [2] to complete this sentinel network. Indicators continuously collected through this surveillance system are summarised in Table 1 . Statistical analysis is carried out using Stata and Excel.

\section{Epidemiological and virological}

surveillance of acute respiratory infections

by the sentinel practitioner network

Forty general practitioners and two paediatricians participate in the influenza sentinel network $(4.9 \%$ of the total general practitioners). They are located all over the island and report on a weekly basis their total number of consultations and the number of acute respiratory infections (ARI) according to the following case definition: sudden onset of fever $>38^{\circ} \mathrm{C}$, cough, associated or not with other symptoms (breathing difficulty, headache, etc.). Weekly ARI consultation rates are calculated and monitored in order to follow the epidemiological situation of influenza. Furthermore, every physician of the sentinel network is expected to collect a nasal swab from the first two patients of the week presenting with ARI symptoms with an onset of less than three days. This sampling allows surveillance of the viruses circulating in Réunion. Swabs are tested by RT-PCR influenza in the reference hospital laboratory (CHU, Réunion).

\section{Hospital emergency departments and} surveillance of severe cases of influenza There are four emergency departments in Réunion. In all of them, a computerised medical file is filled in during each medical consultation, regardless of the diagnosis. Medical files are automatically extracted and transmitted daily to the French Institute for Public Health Surveillance (InVS, Paris, France). The regional office (Cire OI) can then monitor daily number of visits for all causes including ARI. In addition to this surveillance, all severe influenza cases observed in Réunion are reported by clinicians to the Cire Ol through a standardised form including epidemiologic, demographic 


\begin{tabular}{|c|c|c|c|c|c|c|}
\hline \multirow[b]{2}{*}{ Location } & \multicolumn{2}{|c|}{2009} & \multicolumn{2}{|c|}{$2010 / 11$} & \multicolumn{2}{|r|}{$2011 / 12$} \\
\hline & Epidemic period & $\begin{array}{c}\text { Influenza } \\
\text { virus isolated }\end{array}$ & Epidemic period & $\begin{array}{c}\text { Influenza } \\
\text { virus isolated }\end{array}$ & Epidemic period & $\begin{array}{c}\text { Influenza } \\
\text { virus isolated }\end{array}$ \\
\hline Réunion & $\begin{array}{c}\text { Week } 30 \text { to } \\
\text { week } 42 \text { (2009) }\end{array}$ & $\begin{array}{l}\text { - } A\left(\mathrm{H}_{1} \mathrm{~N}_{1}\right) \mathrm{pdmog} \\
\text { - }\end{array}$ & $\begin{array}{c}\text { Week } 35 \text { to } \\
\text { week } 47(2010)\end{array}$ & $\begin{array}{l}\text { - Predominantly } \\
\text { A }\left(\mathrm{H}_{1} \mathrm{~N}_{1}\right) \text { pdmo9 } \\
\text { - }\end{array}$ & $\begin{array}{l}\text { Week } 16 \text { to } \\
\text { week } 30 \text { (2011) }\end{array}$ & $\begin{array}{l}\text { - Predominantly } \mathrm{A}\left(\mathrm{H}_{3} \mathrm{~N}_{2}\right) \\
\text { - B }\end{array}$ \\
\hline $\begin{array}{l}\text { Mainland } \\
\text { France }\end{array}$ & $\begin{array}{l}\text { Week } 43 \text { to } \\
\text { week } 52 \text { (2009) }\end{array}$ & $\begin{array}{l}\text { - } A\left(\mathrm{H}_{1} \mathrm{~N} 1\right) \mathrm{pdmog} \\
\text { - }\end{array}$ & $\begin{array}{l}\text { Week } 51 \text { (2010) to } \\
\text { week } 7 \text { (2011) }\end{array}$ & $\begin{array}{l}\text { - Predominantly } \\
\text { A(H1N1)pdmo9 } \\
\text { - B }\end{array}$ & $\begin{array}{c}\text { Week } 6 \text { to } \\
\text { week } 14 \text { (2012) }\end{array}$ & $\begin{array}{l}\text { - Predominantly } A\left(\mathrm{H}_{3} \mathrm{~N}_{2}\right) \\
\text { - } B \\
\text { - Occasionally } \mathrm{A}\left(\mathrm{H}_{1} \mathrm{~N}_{1}\right) \text { pdmog }\end{array}$ \\
\hline
\end{tabular}

a In the southern hemisphere the influenza season is between May and October. In the northern hemisphere it is during the winter months.

and clinical data. A severe case of influenza is defined as a patient with a laboratory-confirmed influenza infection (positive RT-PCR for influenza virus) admitted for more than 24 hours to an intensive care unit (ICU) or as a patient who died.

\section{Mortality surveillance}

The National Institute for Statistics (Institut National de la Statistique et des Etudes Économiques, Insee) conducts the administrative recording of deaths from all causes in France. For several years, Insee has been monitoring and centralising daily mortality in France including Réunion. In case of an influenza epidemic on the island, we analyse this total number and excess of deaths from all causes. This system is completed by analysis of all death certificates received by the regional public health authority that mention 'influenza'. These certificates are recorded as influenzaassociated deaths. Electronic death certification which is being implemented in France is being used by the Intensive Care Department of Saint-Denis Hospital, and is analysed in real time by the Cire.

\section{Results}

Data from the physician sentinel network and from virological surveillance for 2009-2011 are presented in the Figure.

Since 2009, three successive influenza epidemics occurred in Réunion. The largest was observed in 2009 , with consultation rates for ARI reaching $21 \%$. In 2010 and especially in 2011, epidemics were much weaker with a maximal percentage of ARI of $8.5 \%$ and $6.7 \%$, respectively. The three of them started during the southern hemisphere winter (between June and August), and lasted between 8 and 10 weeks. Numbers of visits from emergency rooms show the same pattern of consultation rates of sentinel network [4-5].

Regarding circulating strains, B viruses were predominant at the beginning of the 2009 epidemic, but they were rapidly evicted once $\mathrm{A}\left(\mathrm{H}_{1} \mathrm{~N}_{1}\right)$ pdmog circulation started (Table 2).
In the 2010 influenza season in Réunion, the pandemic virus was predominant again, but a constant co-circulation of B viruses was observed. In 2011, the $\mathrm{A}\left(\mathrm{H}_{3} \mathrm{~N}_{2}\right)$ virus has been circulating almost exclusively; A/Victoria/210/2009 strain was notably identified. No $\mathrm{A}\left(\mathrm{H}_{1} \mathrm{~N}_{1}\right)$ pdmo9 circulation was detected and only few instances of $B$ virus circulation were identified. During the three influenza seasons, the same viruses were identified in mainland France, except in 2011/12 when $\mathrm{A}\left(\mathrm{H}_{1} \mathrm{~N}_{1}\right)$ pdmog was occasionally identified.

During the influenza $A\left(\mathrm{H}_{1} \mathrm{~N}_{1}\right)$ pdmog pandemic in 2009, the Réunion surveillance system showed a nine-week epidemic period, with a peak of consultation rate for ARI during week 35 (24-30 August 2009). The number of patients with $\mathrm{A}\left(\mathrm{H}_{1} \mathrm{~N}_{1}\right)$ pdmog infection who consulted a physician was estimated at 66,915 (cumulative attack rate: $8.26 \%$ [3]. After 2009, epidemic periods of influenza were observed in Réunion but they were weaker.

Characteristics of severe cases during 2009-2011 are presented in Table 3.

Chronic respiratory disease was the most common comorbidity every year. The non-negligible proportion of obese patients has to be noted, as well as the presence of one pregnant woman in 2009 and two in 2010, without any other risk factor for severity. In 2010, a particularly high severity among patients hospitalised in ICU could be observed: all 14 patients needed respiratory assistance. Half of them needed extracorporeal membrane oxygenation or high frequency oscillation. Half of the patients hospitalised in ICU died.

\section{Discussion}

Since 2009, the surveillance system of influenza in Réunion allows to have a good and real-time view of the epidemiological situation through monitoring a large range of indicators [5-8]. The epidemiological situation of the pandemic influenza in 2009 has been described in other temperate countries of the southern hemisphere [9] and showed that the epidemiological pattern in Réunion compared well with that of other 
TABLE 3

Characteristics of severe influenza cases ${ }^{\text {, }}$ Réunion, France, 2009-2011

\begin{tabular}{|c|c|c|c|}
\hline Characteristic & $2009(n=24)$ & $2010(n=14)$ & $2011(n=8)$ \\
\hline Sex (female) & 13 & 8 & 3 \\
\hline Mean age in years (range) & $38(0-75)$ & $43(19-76)$ & $52(0-76)$ \\
\hline \multicolumn{4}{|l|}{ Risk factors / comorbidities } \\
\hline Chronic respiratory disease & 10 & 6 & 3 \\
\hline Obesity $^{b}$ & 3 & 5 & 3 \\
\hline Diabetes & 3 & 3 & 2 \\
\hline Pregnancy & 1 & 2 & 0 \\
\hline Age $\geq 65$ years & 4 & 2 & 0 \\
\hline Cardiac disease & 4 & 1 & 4 \\
\hline Immunodeficiency & 1 & 1 & o \\
\hline None & 4 & 0 & 2 \\
\hline \multicolumn{4}{|l|}{ Indicators or signs of severity } \\
\hline Acute respiratory distress syndrome & 13 & 14 & 3 \\
\hline Respiratory assistance $^{c}$ & 15 & 13 & 3 \\
\hline Extracorporeal membrane oxygenation ${ }^{\mathrm{d}}$ & 3 & 5 & 1 \\
\hline High frequency oscillation ${ }^{e}$ & 0 & 2 & 0 \\
\hline Death & 5 & 7 & 1 \\
\hline
\end{tabular}

a Patients with a biologically-confirmed influenza infection admitted to an intensive care unit.

b Body mass index $>30$.

The patient undergoes assisted ventilation by mechanical pump and endotracheal intubation.

Application of a life support system that circulates the blood through an oxygenating system, which may consist of a pump, a membrane oxygenator, and a heat exchanger.

e High frequency oscillation ventilation is the delivery of small tidal volumes to the infant at fast frequencies. Both Inspiration and expiration are active, therefore reducing the likelihood of gas trapping.

temperate southern hemisphere countries such as New Zealand [10], South Africa [11], Australia [12-14], with $A\left(\mathrm{H}_{1} \mathrm{~N}_{1}\right)$ pdmog virus circulating predominantly. This pattern was indicative for what was going to happen in the forthcoming influenza season in the northern hemisphere. In 2010, a weaker epidemic was observed with also a non-negligible number of severe cases [15]. Similar patterns were then observed in Europe [16], confirming that surveillance of influenza in Réunion can also provide useful data to anticipate what can be expected a few months later in northern hemisphere countries in terms of dynamics, severity and circulating viruses. During the last three years, our epidemiological data identified obesity and diabetes as risks factors of severe form of influenza. This was confirmed a few months later in Europe $[17,18]$.

During the 2011 season, we did not observe any $A\left(H_{1} N_{1}\right) p d m o g$ circulation, which is very specific to our island since all the other southern hemisphere countries detected it [19]. In Réunion, the $A\left(\mathrm{H}_{3} \mathrm{~N}_{2}\right)$ virus circulated almost exclusively whereas it was not the predominant influenza A subtype in any temperate southern hemisphere countries considered as sentinels for the northern hemisphere [3]. A few months later, in France, Ireland, Spain and the United Kingdom, the influenza season 2011/12 started during the last weeks of 2011 and has been dominated by influenza $A\left(\mathrm{H}_{3}\right)$ viruses with minimal circulation of influenza $A\left(\mathrm{H}_{1} \mathrm{~N}_{1}\right)$ pdmog and $B$ viruses [20]. Since 2009, virus circulation, epidemiological trends and health impact in Réunion were therefore similar to those observed in Europe. It confirms that Réunion might be even a more suitable predictor for Europe than other southern hemisphere countries.

In conclusion, influenza surveillance in Réunion may give reliable timely information which should be considered apart from the surveillance in mainland France. In addition to data from other southern hemisphere temperate countries, influenza surveillance in Réunion should be taken into consideration in order to make predictions of what can be expected in the corresponding winter season in northern hemisphere countries.

Furthermore, this information can be very useful for epidemiological surveillance in the Indian Ocean. An international network was initiated in 2006 by the Indian Ocean Commission: the epidemiological surveillance and alert control (SEGA - Surveillance Epidémiologique Gestion des Alerte) [21]. One of its objectives is to exchange epidemiological information on influenza 
surveillance. Real-time data on the epidemiological situation of influenza and circulating viruses are therefore available through this network for Comoros, Réunion, Madagascar, Mauritius and Seychelles.

\section{References}

1. Institut national de la statistique et des études économiques (Insee). Évolution de la population totale au 1er janvier 2011

[Total Population as of 1 January 2011]. Insee 2011. French. Available from: http://www.insee.fr/fr/themes/tableau. asp?reg_id=24\&ref_id=poptc02101

2. D'Ortenzio E, Do C, Renault P, Weber F, Filleul L. Enhanced influenza surveillance on Réunion Island (southern hemisphere) in the context of the emergence of influenza A(H1N1)v. Euro Surveill. 2009;14(23):pii=19239. Available from: http://www.eurosurveillance.org/ViewArticle. aspx?Articleld $=19239$

3. Lopez Chavarrias V, Broberg E, Nicoll A. Preliminary implications for Europe of the 2011 influenza season in five temperate southern hemisphere countries. Euro Surveill. 2011;16(50): pii=20044. Available from: http://www. eurosurveillance.org/ViewArticle.aspx?Articleld =20044

4. Lassalle C, Grizeau P, Isautier H, Bagnis O, Michault A, Zeller $H$. Surveillance épidémiologique de la grippe et de la dengue. La Réunion, 1996. [Epidemiological surveillance of influenza and dengue. Reunion, 1996]. [French]. Bull Soc Pathol Exot. 1998;91(1):61-3.

5. D’Ortenzio E, Renault $P$, Jaffar-Bandjee $M C$, Gaüzère BA, Lagrange-Xélot $M$, Fouillet $A$, et al. A review of the dynamics and severity of the pandemic $A\left(\mathrm{H}_{1} \mathrm{~N}_{1}\right)$ influenza virus on Réunion island, 2009. Clin Microbiol Infect. 2010;16(4):309-16.

6. Filleul L, Durquéty E, Baroux N, Chollet $P$, Cadivel A, Lernout T. Le développement de la surveillance non spécifique à Mayotte et à la réunion dans le cadre de l'épidémie de grippe à virus $A\left(\mathrm{H}_{1} \mathrm{~N}_{1}\right) 2009$. [The development of non-specific surveillance in Mayotte and Reunion Islands in the context of the epidemic of influenza $A\left(\mathrm{H}_{1} \mathrm{~N}_{1}\right)_{2009}$ ]. BEH. 2010;24-25-26: 283-6. French. Available from: http://www.invs.sante.fr/beh/2010/24_25_26/ beh_24_25_26_2010.pdf

7. Brottet $E$, Jaffar-Bandjee MC, Valette $M$, Polycarpe D, Filleul L. Surveillance épidémiologique et virologique de la grippe à la Réunion : un hiver austral 2011 très calme. [Epidemiological and virological surveillance of influenza in Réunion: a calm austral winter 2011]. Bulletin de veille sanitaire. 2011;14:5-7. French. Available from: http://www. invs.sante.fr/Publications-et-outils/Bulletin-de-veillesanitaire/Tous-les-numeros/Ocean-indien-Reunion-Mayotte/ Bulletin-de-veille-sanitaire-ocean-Indien.-N-14-Decembre-2011

8. Renault P, D’Ortenzio E, Kermarec F, Filleul L. Pandemic influenza 2009 on Réunion Island: A mild wave linked to a low reproduction number. PLoS Curr. 2010;2:RRN1145.

9. Baker MG, Kelly H, Wilson N. Pandemic $\mathrm{H}_{1} \mathrm{~N}_{1}$ influenza lessons from the southern hemisphere. Euro Surveill. 2009;14(42):pii=19370. Available from: http://www. eurosurveillance.org/ViewArticle.aspx?Articleld =19370

10. Baker MG, Wilson N, Huang QS, Paine S, Lopez L, Bandaranayake $D$, et al. Pandemic influenza $A\left(\mathrm{H}_{1} \mathrm{~N}_{1}\right) v$ in New Zealand: the experience from April to August 2009. Euro Surveill. 2009;14(34):pii=19319. Available from: http://www. eurosurveillance.org/ViewArticle.aspx?Articleld=19319

11. Archer BN, Cohen C, Naidoo D, Thomas J, Makunga C, Blumberg $\mathrm{L}$, et al. Interim report on pandemic $\mathrm{H}_{1} \mathrm{~N}_{1}$ influenza virus infections in South Africa, April to October 2009: Epidemiology and factors associated with fatal cases. Euro Surveill. 2009;14(42):pii=19369. Available online: http://www. eurosurveillance.org/ViewArticle.aspx?Articleld $=19369$

12. Kelly H, Grant K. Interim analysis of pandemic influenza $\left(\mathrm{H}_{1} \mathrm{~N}_{1}\right) 2009$ in Australia: surveillance trends, age of infection and effectiveness of seasonal vaccination. Euro Surveill. 2009;14(31):pii=19288. Available from: http://www. eurosurveillance.org/ViewArticle.aspx?Articleld=19288

13. New South Wales public health network. Progression and impact of the first winter wave of the 2009 pandemic $\mathrm{H}_{1} \mathrm{~N}_{1}$ influenza in New South Wales, Australia. Euro Surveill. 2009;14(42): pii=19365. Available from: http://www. eurosurveillance.org/ViewArticle.aspx?Articleld=19365

14. Fielding JE, Higgins N, Gregory JE, Grant KA, Catton MG, Bergeri I, et al. Pandemic $\mathrm{H}_{1} \mathrm{~N}_{1}$ influenza surveillance in Victoria, Australia, April - September, 2009. Euro Surveill. 2009;14(42):pii=19368. Available online: http://www. eurosurveillance.org/ViewArticle.aspx?Articleld =19368
15. Gaüzère BA, Bussienne F, Bouchet B, Jabot J, Roussiaux A, Drouet $D$, et al. [Severe cases of $A\left(\mathrm{H}_{1} \mathrm{~N}_{1}\right) v_{2} 009$ infection in Réunion Island in 2009 and 2010]. Bull Soc Pathol Exot. 2011;104(2):97-104. [French].

16. Amato-Gauci A, Zucs P, Snacken R, Ciancio B, Lopez V, Broberg $E$, et al. Surveillance trends of the 2009 influenza $A\left(\mathrm{H}_{1} \mathrm{~N}_{1}\right)$ pandemic in Europe. Euro Surveill. 2011;16(26): pii=19903. Available from: http://www.eurosurveillance.org/ViewArticle. aspx?Articleld=19903

17. Pebody RG, McLean E, Zhao H, Cleary P, Bracebridge S, Foster K, et al. Pandemic Influenza A (H1N1) 2009 and mortality in the United Kingdom: risk factors for death, April 2009 to March 2010. Euro Surveill. 2010;15(20):pii=19571. Available from: http://www.eurosurveillance.org/ViewArticle. aspx?Articleld $=19571$

18. World Health Organization (WHO). Review of the 2010-2011 winter influenza season, northern hemisphere. Wkly Epidemiol Rec. 2011;86(22):222-7.

19. World Health Organization (WHO). Review of the 2011 winter influenza season, southern hemisphere. Wkly Epidemiol Rec. 2011;86(44):488-96.

20. Beauté J, Broberg E, Plata F, Bonmarin I, O’Donnell J, Delgado $C$, et al. Overrepresentation of influenza $A\left(\mathrm{H}_{1} \mathrm{~N}_{1}\right)$ pdmog virus among severe influenza cases in the $2011 / 12$ season in four European countries. Euro Surveill. 2012;17(9):pii=20105. Available from: http://www.eurosurveillance.org/ViewArticle. aspx?Articleld $=20105$

21. Flachet $L$, Lepec $R$. Le réseau Sega, la surveillance épidémiologique dans l'océan Indien. [Sega network, epidemiological surveillance in the Indian Ocean]. Bulletin de veille sanitaire. 2011;13:11-13. Available from: http://www.ars. ocean-indien.sante.fr/fileadmin/Oceanlndien/Internet/Veille et securite sanitaire/Gestion de crise sanitaire/CIRE/BVS/ BVS_13_thematique_Veille_sanitaire_novembre_2011.pdf 